\title{
JUSTIFICATION OF THE PROBLEM OF GROUND TRAINING FOR COMBAT FLIGHTS OF FUTURE TACTICAL AVIATION PILOTS IN A MODERN DYNAMIC OPEN EDUCATIONAL SPACE
}

\section{Roman Nevzorov ${ }^{1}$}

DOI: https://doi.org/10.30525/978-9934-26-076-6-13

The dynamics of development and variability of the main social processes in the modern world has been consistently high over the past decades. Global trends in integration, massization, openness, informatization and gadzhitolization significantly affect all spheres of society, including education.

The problem of the «modern educational space» is being discussed in international scientific circles. Thus, a concentrated interpretation of this phenomenon, characteristic of most special works on the philosophy of education in Eastern Europe, was proposed at the end of the twentieth century by B. Gershunsky: «an integral and dynamic system, a complex multi - level and multifunctional education, within the framework of common basic standards ensures the interdependence and interaction of its components, as well as as a complex hierarchical structure, a pyramid of spaces of different levels-global, continental, separate country and region, local (separate educational institution), family, personal» [1, p. 15].

Already at the beginning of the XXI century, I. Borisenko, from the standpoint of trends in informatization and virtualization of modern education, defined the educational space as a «conditioned «place» in society, in which certain relations and connections are formed with the help of subjects, where special activities of various state, public and other systems for the development of the individual and his socialization are carried out» [2, p. 18]. At the same time, she rightly emphasizes that the category «educational space» is one of the most abstract and general concepts of the philosophy of education.

A. Tsymbalaru points out the multi-dimensionality and diversity of the content field of this definition. Based on the etymological analysis of its components and content analysis of numerous modern approaches and interpretations, it suggests considering the educational space as «this is a pedagogical reality in which there is a meeting, interaction, comprehension and cognition by the individual of its surrounding elements-carriers of culture

\footnotetext{
${ }^{1}$ Ivan Kozhedub Kharkiv National Air Force University, Ukraine
} 
(educational environment), which provides subjectivation and progressive development of objects (persons involved and objects)... as a system of pedagogical factors and conditions for Mastering by the individual in the process of becoming a specially organized pedagogical environment, what can be the object of purposeful pedagogical influence, formation» [3, p. 45].

The analysis of sources allows us to state that the modern educational space is considered not only as a social phenomenon, but also as a functionalspatial construct in which professional development and self-realization of the individual takes place. In our opinion, the modern dynamic open educational space should be considered as a complex multi-level metasystem of the global educational environment, within which the latest pedagogical ideas and approaches are generated and tested; the formation of new learning models; identification of key modern professional and educational competencies and which is characterized by maximum openness of didactic content, forms and tools, as well as their exchange on a global scale.

In practice, this means that it acts as a accumulator and place of empirical verification of both fundamental pedagogical concepts and doctrines, models and approaches of teaching, as well as specific methods and methods of teaching. Its main characteristics are maximum openness and exchange of ideas, interpenetration of methodological forms and tools, transfer of part of practical training to the virtual plane.

Under such conditions, any traditional, established pedagogical subsystems are «doomed» to rethinking and modernization.

Ground-based combat flight training (ground combat training) of future tactical aviation pilots just belongs to this type of pedagogical subsystems. Having appeared as a pedagogical phenomenon in the first half of the twentieth century, at the request of wartime, ground training in combat flights became an integral part of the professional training of military pilots in every Aviation country in the world. However, its domestic counterpart has not been formed into an autonomous didactic subsystem with its own scientific and theoretical apparatus and a pedagogically based model. In our deep conviction, the reason for this situation was and partly remains an underestimation of this component of professional training of military pilots. For a long time, its significant role and significance were ignored under the influence of the authority of the theory and practice of the Soviet model of Flight Training Methods and scientific and practical provisions of aviation psychology and military pedagogy.

Meanwhile, the system of professional training of military flight personnel, including tactical aviation in the domestic institution of Higher Military Education (SVVO) (in Ukraine it is the only one - Kharkiv National University of the Air Forces named after Ivan Kozhedub (KHNUPS)) is a 
complex organizational formation consisting of different stages of training, united by the unity of a common goal of functioning. Ground training performs a propeudic role in its structure: it «immerses» a cadet-pilot in a military specialty, contributes to the formation of primary professional skills, and reveals the professionogram of the future specialty. At the same time, the share of the relevant educational program is implemented in virtual conditions (during special simulators in aircraft cabins and on special simulators), which fully corresponds to the modern characteristics of the educational environment, psychologically and physically prepares cadets for actual flight training and reduces the cost of extremely expensive practical training of future pilots.

It is also worth noting that the official Euro-Atlantic Initiative of our state, which requires the accession and introduction of NATO best standards and practices in the Air Forces of the armed forces of Ukraine, fully corresponds to the content and forms of ground combat training. Provided that the material base of KHNUPS is equipped with modern simulators-systems of the NATO model, the implementation of these standards is really intensified both in time and content. In addition, it is several orders of magnitude cheaper than the long and complex rearmament of domestic military aviation with new types of military aircraft. In fact, as long as such re-equipment continues, the teaching, instructor and Cadet staff will have time to prepare professionally for it.

However, only technical modernization is not enough here. The content of ground training for combat flights of future tactical aviation pilots in the SVVO should be significantly revised and updated. First of all, we need a solid theoretical foundation - the development and implementation of an effective pedagogical training system (as an autonomous subsystem of professional training) based on a pedagogically proven and proven theoretical model.

Resume. In the conditions of functioning of a modern dynamic open educational space, ground training in combat flights should be considered as an autonomous pedagogical subsystem of professional training of future tactical aviation pilots, capable of ensuring an effective transition of domestic air forces to advanced NATO standards and a real increase in their combat power in the most optimal way.

\section{References:}

1. Gershunskij B. S. (1997) Filosofija obrazovanija dlja XXI veka: v poiskah praktiko-orientirovannyh obrazovatel'nyh koncepcij [Philosophy of education for a XXI century: in search of the practical oriented educational conceptions]. Moscow: InterDialekt+. (in Russian)

2. Borisenko I. G. (2016) Virtualizacija otechestvennogo obrazovatel'nogo prostranstva: social'no-filosofskij analiz [Virtualization of home educational space: 
socially-philosophical analysis] (PhD Thesis), Krasnoyarsk: Siberian Federal University. (in Russian)

3. Tsimbalaru A. D. (2016). Osvitnij prostir: sutnistj, struktura i mekhanizmy stvorennja [Educational space: essence, structure and mechanisms of creation]. Ukrajinsjkyj pedaghoghichnyj zhurnal, no. 1, pp. 41-50. 